\title{
Locating Early Modern Women's Participation in the Public Sphere of Botany: Agnes Block (1629-1704) and Networks in Print
}

\section{Catherine Powell}

Catherine Powell is a PhD candidate in art history at the University of Texas at Austin. She is currently a Kress Institutional Fellow at the Leiden University Centre for the Arts in Society (LUCAS). Her research focuses on the role of early modern women in the creation, production, and patronage of art in the Low Countries. Her dissertation concerns the patron, collector, and amateur botanist Agnes Block (1629-1704). In particular, Powell examines Block's use of and reliance upon networks of artists and expert and amateur botanists in the establishment of her reputation and in her self-representation.

\begin{abstract}
Although we are frequently confronted with an image of early modern Dutch women as existing primarily, if not exclusively, within the realm of household management, the reality was far more nuanced. A case study of Agnes Block (1629-1704) shows that by focusing on relationships, she succeeded in participating in the creation and dissemination of knowledge of botany in the public sphere and achieved recognition in that sphere, notwithstanding the institutional limits imposed upon her due to her gender. By adapting our methodological and analytical frameworks, in this case by looking to social networks and the power of print media, we can recover the stories of early modern women that are otherwise obscured in the archives and write them into history.
\end{abstract}

Keywords: botany, Agnes Block, female agency, public sphere, informal institutions

DOI 10.18352/emlc.147 - URL: http://www.emlc-journal.org

Publisher: Stichting EMLC, supported by Utrecht University Library Open Access Journals | The Netherlands Copyright: The Author(s). This work is licensed under a Creative Commons Attribution-NonCommercial 4.0 International License. 


\section{Locating Early Modern Women's Participation in the Public Sphere of Botany: Agnes Block (1629-1704) and Networks in Print}

\section{Catherine Powell}

A lasting, though partially inaccurate, impression of early modern Dutch women is that provided by the paintings of Johannes Vermeer, Gabriël Metsu, and Gerard ter Borch: a milkmaid, a housekeeper, a mother delousing a child's hair, or a young woman reading a long-expected letter, presumably from her husband. Even when depicted in a leading role whether directing the day's musical performance (Pieter de Hooch) or teaching a young girl to write (Caspar Netscher) - the realm of early modern women is frequently depicted as confined to household management. The reality, however, was far more nuanced, as shown by the case of amateur botanist and patron Agnes Block (1629-1704).

My objective in this essay is to explore, through a case study of Block, how early modern women participated and contributed to the public discourse related to the development and creation of botanical knowledge. Drawing upon social network analysis, I consider how Block, a wealthy liefhebber without a Latin education or access to membership to most formal institutions - such as universities and institutes of higher learning, academies such as the Royal Society, and civic office - nevertheless entered the upper echelons of the exchange of information and ideas and discovery in the then-rapidly evolving field of botany. I place particular focus onto the role of print publications not only in shaping early modern public discourse on botany, but also as a source for locating Block and her network.

1 The expression liefhebber is commonly translated as amateur, lover of art, and virtuoso, or used alternatively with the French term curieux. See for a lexicographical overview of Dutch seventeenth-century art historical sources that use the word liefhebber: https://lexart.fr/terms/view/1843 (Accessed 2 December 2020). I am grateful to Dr. Claudia Swan for providing me with this reference. This essay is drawn from a larger dissertation research project. This research was made possible thanks to funding from the Department of Art and Art History at the University of Texas at Austin, the Renaissance Society of America, the Herzog August Bibliothek, Wolfenbüttel, and an Institutional Fellowship at the Leiden University Centre for the Arts in Society (LUCAS), supported by the Samuel H. Kress Foundation. The essay expands upon a presentation on the same topic given at the University of Amsterdam's Kunstgeschiedenis Onderzoeksbijeenkomst in January 2020. I wish to thank all participants for their constructive comments and suggestions. I am particularly grateful to Dr. Judith Noorman for her insights on this topic and to Dr. Stijn Bussels and Dr. Claudia Swan for their helpful feedback. As always, Dr. Jeffrey Chipps Smith provided invaluable assistance with his thoughtful comments and probing questions. 
The scholarship of the last few decades has cast light onto long-forgotten women artists. Literary and economic historians have shone a spotlight on the significant participation of early modern women in the Republic of Letters and on the financial contributions to the household made by early modern women in the Dutch Republic, rectifying to a certain degree the misunderstood role and place of early modern women. ${ }^{2}$ Nevertheless, much remains to be examined, particularly with respect to female agency and women's participation in the creation and dissemination of natural knowledge during the seventeenth century. Whereas considerable work has been done regarding the closely-related role of women in the provision of traditional herbal remedies, surprisingly little scholarship has been published on the topic at hand, particularly regarding the Dutch Republic. ${ }^{3}$

One relevant exception is Florike Egmond's illuminating examination of Carolus Clusius's correspondence and exchange with women at the end of the sixteenth century and in the first decade of the seventeenth century. However, the women with whom Clusius dealt were different from Block, as was the socio-cultural environment in which Block operated, nearly one century later. ${ }^{4}$ Amongst other things, Clusius's exchanges took place at a time before the establishment of scientific academies and institutionalisation of early modern science. These circumstances are markedly different from the world in which Agnes Block operated. That the role of early modern Dutch women in the creation and dissemination of natural knowledge is understudied is due partly to the lack of female ego-documents (such as diaries and travel journals, and personal catalogues), and partly due to the application of ill-fitting monographic and institution-driven approaches, developed based on our understanding and general acceptance of male-dominated power structures.

What this case study demonstrates is that even women who did not benefit from a comprehensive humanist education (very few women were as fortunate as Anna Maria van Schurman in that regard), or who did not belong to noble or scientific families, could and did expand their participation in society by entering the early scientific public discourse, albeit in unexpected ways. Arguably, Block achieved a level of fame that was uncommon, although her contemporary Maria Sibylla Merian (1647-1717), whose services she retained, also achieved celebrity. However, there is no reason to think that Block is not representative of a class of wealthy, although not formally educated or necessarily connected, early modern women. Given the cultural significance of gardening and botany in the Dutch Republic in the seventeenth century, it is likely that many more women shared her passion, developing expertise that they went on to disseminate, albeit perhaps not in the ways expected by historians. By rethinking how we approach our research and by adapting our methodologies, we have the opportunity to include women and therefore change our view of their role and recontextualise that of other actors in history.

2 More recent noteworthy work includes Van der Stighelen et al., Michaelina Wautier; Van der Stighelen and Huys, Vrouwenstreken; Sutton, Women Artists and Patrons; Moran and Pipkin, Women and Gender in the Early Low Modern Countries; De Jeu, 't Spoor der dichteressen; Pal, Republic of Women; Veldman and Hoyle, Crispijn de Passe; Ogilvie, A Bitter Living; Ogilvie, European Guilds; Schmidt, 'The Profits of Unpaid Work'.

3 Backer's Er stond een vrouw in de tuin is a welcome addition to the field. On the relationship between women and early modern medicine and remedies, see Rankin, 'Medicine for the uncommon woman'; Rankin, 'Exotic Materials and Treasured Knowledge'; Hunter and Hutton, Women, science, and medicine.

4 Egmond, The World of Carolus Clusius, 55. 
In reaching my conclusions, I consider Agnes Block's passion for botany and her devotion to Vijverhof in the context of the broader national investment and interest in gardens and the environment. The sweeping popularity of gardens, naturalia, and exotica in the Dutch Republic of the seventeenth century places Block's involvement within a significant, non-marginal discourse. I also explore the traditional dichotomy between the private and public spheres and examine the institutional barriers early modern women experienced when seeking to participate in the public sphere of natural knowledge. Exclusion from the most significant formal institutions that shaped natural knowledge meant that Block participated in the creation and dissemination of botanical knowledge in a different manner from her male contemporaries. Nevertheless, a close review of seventeenth-century botanical treatises written by celebrated experts confirms that Block succeeded in doing so. She was a member of their elite network, and made a lasting contribution to the creation and dissemination of botanical knowledge in the public sphere.

\section{Agnes Block and a Very Dutch Passion for Botany and the Exotic}

Born in 1629, Agnes Block was an orphan from an affluent merchant Mennonite family. ${ }^{5}$ The second of four siblings, it is unclear when her parents died, although it would have been after 1632, the year her youngest sister was born. Most of what we know about Block post-dates her arrival in the household of her maternal uncle David Rutgers (1601-1668) and his wife Susanna de Flines (1607-1677). It was a rich environment, literally and metaphorically. The poet and uncle by marriage Joost van den Vondel (1587-1679) tells us that Block devoured books with uncommon enthusiasm. ${ }^{6}$ Block married twice: to Hans de Wolff (c. 1612-1670) in 1649 and to Sybrand de Flines (1623-1697) in 1674. ${ }^{7}$ Both husbands had children from previous marriages, but Block herself was childless. The Block, de Wolff, and de Flines families were financially successful. Block and many of her relatives lived along the Herengracht, Amsterdam's most exclusive canal. Little is known about Block's home beyond the fact that it had a small garden in the back; the house had a marble-panelled hallway and two rooms for the display of art and beautiful objects (pronkkamers).

The defining moment in Block's life came after the death of her first husband in June 1670, when she bought a country estate in the community of Loenen aan de Vecht, near Utrecht. ${ }^{8}$ She named the estate Vijverhof, after the large ponds she had dug. Although no ground plans or representation of the grounds of the estate survive, we know from a 1702

5 I am indebted to the work of Catharina van de Graft, Agnes Block, who assembled from primary sources the only existing biography of Block. Van der Graft helpfully provided references to the primary sources she consulted, as well as transcriptions of many notarial documents.

6 The comment appears in a poem authored by Van den Vondel on the occasion of Block's marriage to Hans de Wolf: Vondel, 'Mayboom'. The poem was first published in 1650.

7 Marriage contract between Agnes Block and Hans de Wolff, 24 March 1649, transcribed and reproduced in Van de Graft, Agnes Block, 37. For the marriage between Block and de Flines: Amsterdam, Stadsarchief (hereafter SA), Retroacta burgelijke stand, marriage registers, 16 August 1674, fol. $123 \mathrm{r}$.

8 Van de Graft, Agnes Block, 64. 


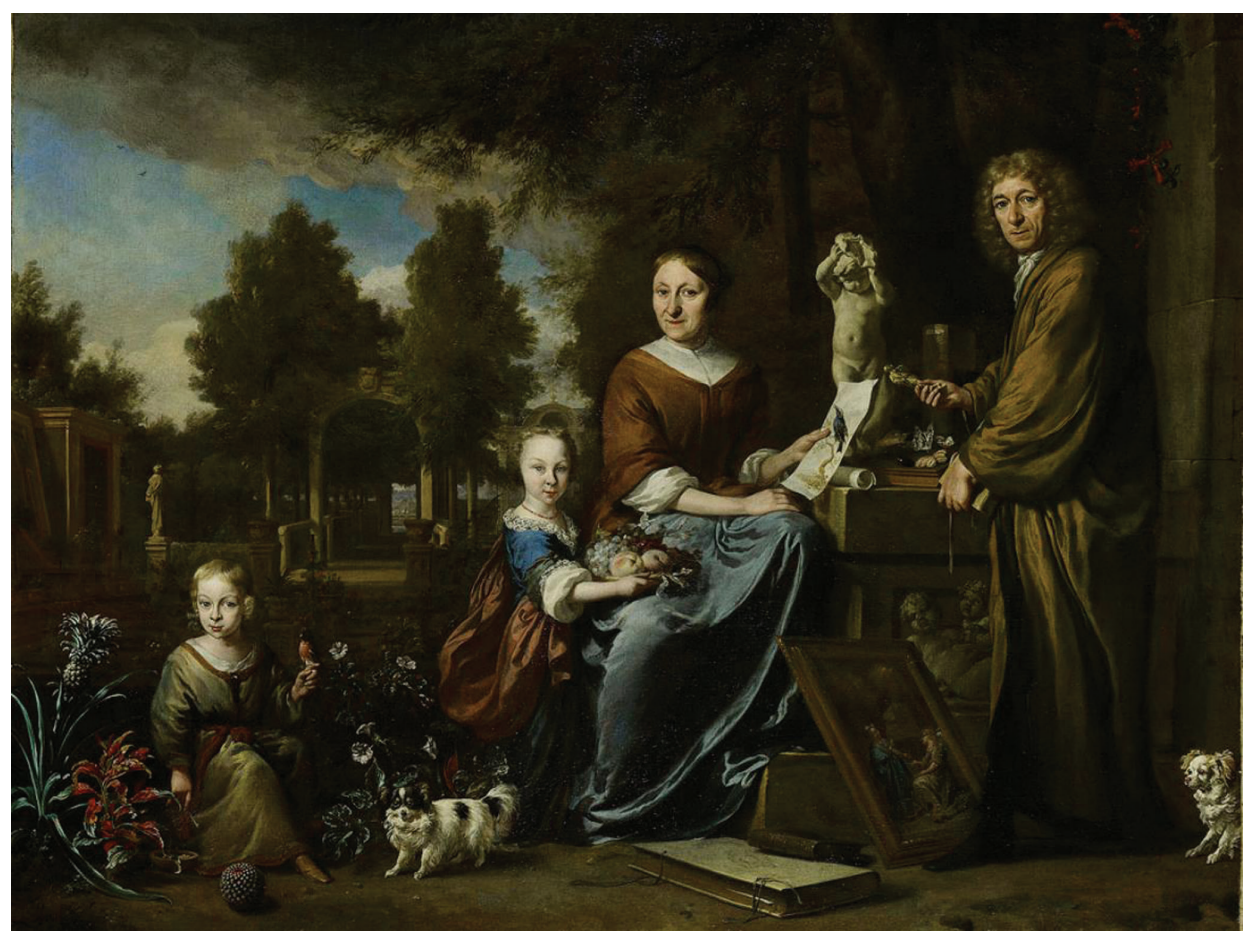

Fig. 1 Jan Weenix, Agneta Block, Sybrand de Flines, and two children atVijverhof on the Vecht, c. 1684, oil on canvas, $84 x 111 \mathrm{~cm}$, Amsterdam, Amsterdam Museum.

poem commissioned by Block from her jurist nephew Gualtherus Blok (c. 1674-1737) that the estate included an orchard, a vegetable garden, ornamental gardens, hedges, an aviary filled with exotic birds, and the orangery where she cultivated rare plants and supposedly grew the first pineapple in Europe. ${ }^{9}$ Block devoted enormous resources to her estate: she acquired the exotic plants, managed construction, and acquired the latest technology, a greenhouse. The country estate proved central to Block's social and 'scientific' relationships. Vijverhof became a site of artistic creativity and production, exchange, knowledge and knowledge production, and ultimately a distinct mark of her identity - one that she chose.

That Block chose to take control of her own identity is illustrated by a portrait commissioned from Jan Weenix (1640-1719), most likely around 1684. The large portrait shows Block, her husband, and two young children in front of Vijverhof, which is portrayed as a lush estate (fig. 1). ${ }^{10}$ In all likelihood, the children were Block's step-grandchildren. Rather unusually for family portraits of the period, it is Block who occupies the centre of the composition and looks directly at the viewer. She holds a drawing of a bird above a table on which are displayed her collections of shells, insect specimens, and a statue; her feet

9 Blok, Vyver-Hof, 3. See also Avery and Calaresu (eds.), Feast \& Fast, 74.

10 See for the most up-to-date information on the portrait: Van Wagenberg-Ter Hoeven, Jan Weenix, II, 140-143. 


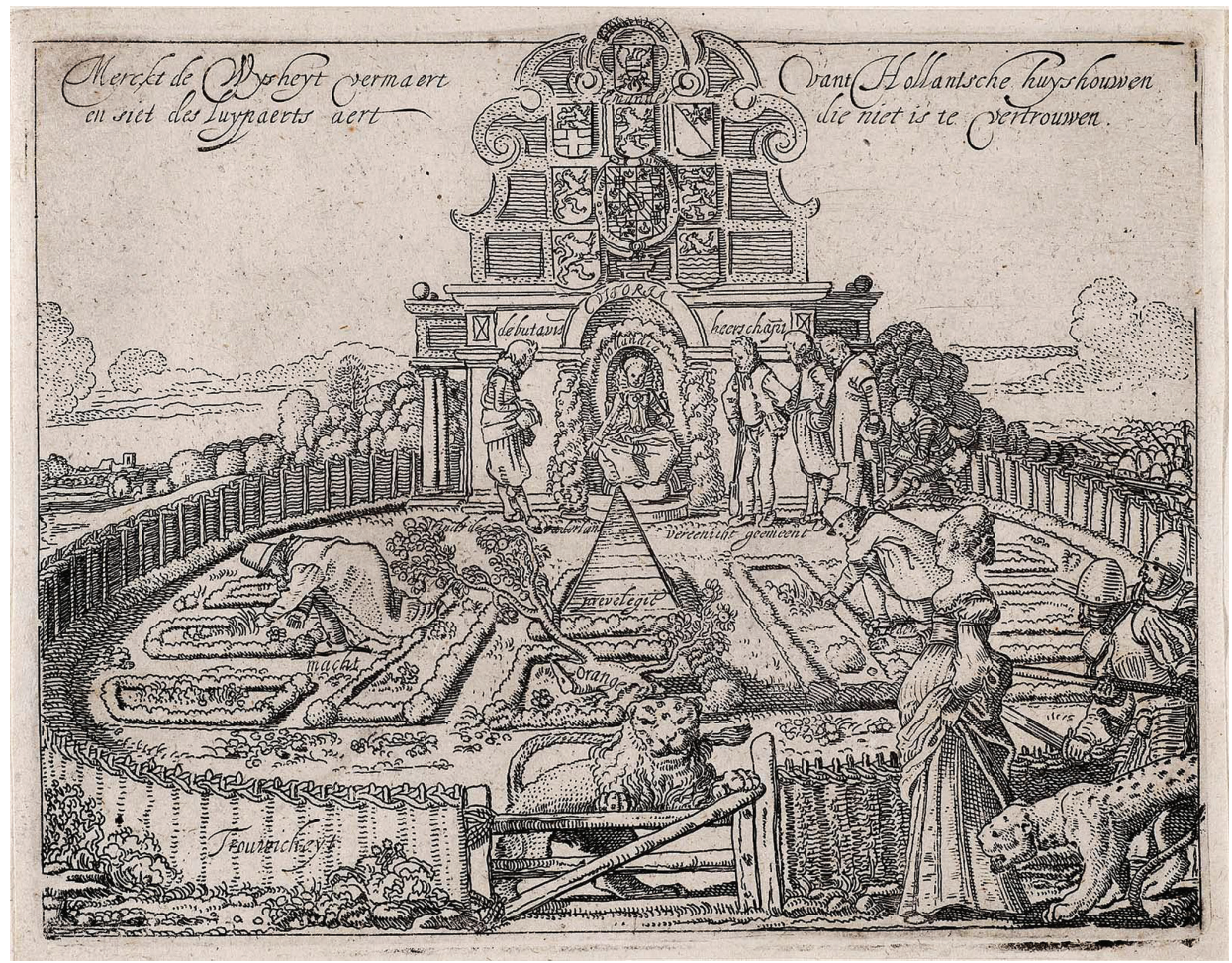

Fig. 2 Willem Pietersz. Buytewech, Allegory of the Twelve Years' Truce, 1615, engraving, 14,1 $x$ 18,4 cm, Amsterdam, Rijksmuseum.

rest on a large portfolio, perhaps representing the four hundred or so botanical drawings and watercolours she had commissioned. Block here presents herself as an important art patron, collector, and knowledgeable amateur botanist - a liefhebber of the highest order.

Block's passion for the countryside and botany were an inextricable part of Dutch national culture and, arguably, with its identity at this time. ${ }^{11}$ One of the foundation myths of the Republic sees the battles of independence with Spain as analogous with the battles waged by the ancient Batavians against the Romans. The task at hand for the victors - and their great and good fortune - was to recreate and inhabit the fertile and prosperous lands of ancient Batavia, as symbolised by an enclosed garden guarded by the Lion of Holland: Hortus Batavus (fig. 2). By the middle of the seventeenth century, botany in the Dutch Republic was an industry, the focus of expeditions and research, and a national passion.

11 Wouter Reh, Clemens M. Steenbergen, and Diederik Aten consider the Dutch landscape 'an inalienable heritage': Reh, Steenbergen, and Aten, Sea of Land, 17. Sellers, Courtly Gardens, 9, observes that 'land reclamation and cultivation and the creation of a peculiarly Dutch geometrical landscape interspersed with canals lay at the foundation of the art of gardening in Holland, so much so that the country itself became identified with a garden and its people with gardeners'. Erik de Jong talks of the Dutch landscape as a 'cultural landscape' and of gardens as 'the most direct interface between nature and culture': De Jong, Nature and Art, ix. 
Burghers invested enormous sums of money in country estates and gardens, giving rise to a garden culture that in fact extended beyond gardens to include country homes and the countryside itself, under the label buitenplaatscultuur - translated literally as 'country place culture'. Although reliable statistics are not available for the seventeenth century, for the period 1710-1730 more than five hundred residents of Amsterdam are recorded as having country homes along the Amstel, Angstel, Gein, Vecht, and Spaarne rivers alone. ${ }^{12}$ Poets celebrated the beauty and freedom that could be found in the garden in thousands of poems known as hofdichten (court and garden poems), a type of literature that proliferated in the Dutch Republic during the second half of the seventeenth century. ${ }^{13}$

In short, Block's passion for her garden and botany was anything but marginal. Thus situated, Block's devotion to Vijverhof and her investment of resources in its development permit us to gain insight into the significance of the public, intellectual (male) discourse on botany in which she wished to participate and, consequently, of the importance of the relationships she nurtured in the furtherance of this objective. Although very much part of her private and therefore domestic realm, Vijverhof gave Block access to and a voice in the public discourse on botany.

\section{A Public Sphere of Botany}

The development of botanical knowledge during the early modern period was a collaborative enterprise that emerged through public debate and exchange. ${ }^{14}$ As Brian Ogilvie has noted, 'it could be the product only of a community'. ${ }^{15}$ The accounts of sailors returning from Batavia or the West Indies regarding the circumstances in which a plant grew and indigenous knowledge regarding a specimen's properties were received by both university professors and apothecaries. ${ }^{16}$

The process of inquiry and knowledge dissemination within the community can often be traced through epistolary relationships. For example, Gijsbert Cuper (1644-1716), best known as a professor of classics and antiquarian, discussed new natural discoveries with Nicolaas Witsen, burgomaster of Amsterdam and collector. Witsen received specimens and information from friends and acquaintances in Surinam, which he shared with Cuper, who proceeded to share their exchanges to other interested parties, including the abbé de Bignon (1642-1743) in Smyrna, who also served as statesman and librarian to Louis XIV:

Mr. Witsen, mayor of Amsterdam, owns a cabinet of snakes \& other animals from the two Indies, \& which are kept in vials filled with brandy or other liquor. In the cabinet I saw large toads which produce their young through their backs. There were three; we could see the young of one half out from the back, and the backs of the others were covered with blisters, from where the young came out when we hit them with

12 Van der Laarse, 'Amsterdam en Oranje', 78.

13 Ruff, Arcadian Visions, esp. chapter six.

14 This was the case not only in Europe, but also in Latin America and throughout Asia, as is made clear by the essays in Curry et al. (eds.), Worlds of Natural History.

15 Ogilvie, The Science of Describing, 1.

16 The assimilation of knowledge from indigenous sources is a complex question investigated by Cook, Matters of Exchange, esp. chapter nine. 
a small stick when they were at the end of their term, when the mothers were still alive. This extraordinary thing so pleased the Tsar of Muscovy, that his Highness asked for the first vial, which Mr. Witsen gave to him. The Curieux will have to work on this \& research how such a wonderful thing can happen. Mr. Witsen promised me to ask his friends in Surinam, because this is where the toads come from, and the distinguished magistrate must ask them to observe exactly everything that concerns the reproduction of these venomous animals..$^{17}$

The key to the significance of this correspondence is contained in the fragment 'the Curieux will have to work on this \& research how such a wonderful thing can happen'. The term curieux is the title given to those devoted to the promulgation of empirical knowledge, and derives from the adjective which denotes 'the mental disposition of being careful, assiduous, and inquisitive'. ${ }^{18}$ What Cuper meant by the fragment quoted above was that the matter of the toad's sexual reproduction was a question for liefhebbers and those interested in the question to research. But how did one participate in this process?

The creation of early modern botanical knowledge depended on individuals possessed with the ability and interest to conduct experiments and make observations, which they could then share with other individuals in order to discuss, debate, refute, and validate so that 'the error or negligence of one is compensated by the accuracy of the other' - and eventually add to a body of knowledge available to similarly situated persons and organizations. ${ }^{19}$ It depended on the existence of a 'public sphere' of botany. By public sphere, I do not mean the realm of all activities that take place outside of the home, nor am I referring to the public sphere represented by the state as a representative of the people. The 'public sphere' (and related public discourse) with which I am concerned is about the shared creation and dissemination of natural knowledge in a public forum, which lends it authority.

The public sphere of botanical knowledge was only one of the many early modern public spheres in existence. This is to say that then, as now, 'there was no single public sphere of knowledge, but such a thing existed to different degrees for different kinds of information'. ${ }^{20}$ In this sense, it is more accurate to speak of various 'publics' to which private individuals could gain access and through which Jürgen Habermas's rational critical discourse materialised. Unlike Habermas, however, I am not concerned with individuals coming together in a bid to influence state action, nor am I concerned with what Habermasian scholars have characterised as a shift from public representation to participation in a bourgeois public sphere. ${ }^{21}$

The public sphere of botany in the seventeenth-century Dutch Republic was shaped to a great extent by formal institutions and printed materials. Furthermore, it had a physical presence: the garden. Although this article focuses on the role of print publications, a brief

17 Cuper to the abbé Bignon, Deventer, 23 November 1708, in Cuperus, Lettres de critique, 212-213.

18 Rieppel, 'Museums and Botanical Gardens'.

19 These words were written by the Dutch military engineer and mathematician Simon Stevin (1548-1620), when he published his collected papers (Wisconstighe gedachtenissen, 1608) in a bid to encourage cooperation in the furtherance of science: cited in Zilsel, The Social Origins of Modern Science, 156.

20 Whaley, 'A Public Sphere before Kant', 25.

21 Gvozdeva, Korneeva, and Ospovat (eds.), Dramatic Experience, 1. Habermas's work has been the subject of continued criticism and refinement. Between 2005 and 2010, Wilson and Yachnin spearheaded a large project examining the concept of 'making publics': Wilson and Yachnin (eds.), Making Publics. 
overview of the roles of the garden as experimental laboratory and of formal institutions in shaping the public sphere of botanical knowledge provides important context and highlights the ways in which each facet of that public sphere intertwined with the others.

As has been extensively explored in recent years, the early modern garden was the locus of experimental science, in effect a laboratory, 'a site of demonstration, where nature was made immutable in time and space..$^{22}$ As Paula Findlen has noted, 'nature had to be reconstructed within a microcosm, creating an artificial world of knowledge in which scholars prodded, dissected, and experimented with nature in order to know it better'. ${ }^{23}$ Botanical gardens, anatomy theatres, and cabinets of curiosities functioned as an extension of the same conceptual space, used and visited by apothecaries, physicians, chemists, botanists, and even the public seeking to experience, understand, and experiment with nature. Individuals drew extensive knowledge from discussions with other amateurs and experts affiliated with institutions. They welcomed them in their own gardens, and learned more about different specimens and methods in the gardens of others. ${ }^{24}$ There, they accumulated knowledge about nature and experience, but also the shared norms and values that made it possible for them to collaborate with others. ${ }^{25}$

Illustrations of gardens from the seventeenth century confirm the social and performative aspects of gardening and botany. In a 1610 print by Willem Isaacsz. Swanenburg (1580-1612) of the botanical garden in Leiden, two couples are arranged on either side of the central axis of the garden, each standing before a leafed archway, looking directly at the viewer, as though inviting us to join them (fig. 3). Other figures dot the symmetrical flower and plant beds: there is a group of students receiving instruction, and other individuals closely observing the specimens before them. The title page for Johann Botsack's Promptuarium allegoriarum sacrarum (1668) emphasises the instructional aspect of the garden (fig. 4). Two men in formal academic robes, one of them with an open book, stand on the edge of a flower bed, deep in discussion. Adriaen Pietersz. van de Venne's drawing of women in a garden (c. 1629-1634) illustrates the informal participatory aspect of gardening and botany. It shows two women in the immediate foreground, one holding a flower while pointing to a flower bed, as if instructing the apparently younger woman behind her; two other figures, one a woman and the other of an indeterminate sex, stand underneath a berceau and lean against the fence, as though they too are participating in this exchange of knowledge (fig. 5).

\section{Formal, Institutional Communities}

As experimental laboratories, gardens - including botanical gardens - had one feature that distinguished them from other spaces of experimentation: they welcomed women.

22 Fleischer, 'Gardening Nature, Gardening Knowledge', 292. Fabrizio Baldassari, in his discussion of gardens as laboratories, refers to them as 'spaces of practical knowledge': Baldassari, 'Introduction', 11.

23 Findlen, 'Anatomy Theaters', 272.

24 Fleischer, 'Beemster Polder', 147.

25 Rieppel, 'Museums and Botanical Gardens'. 


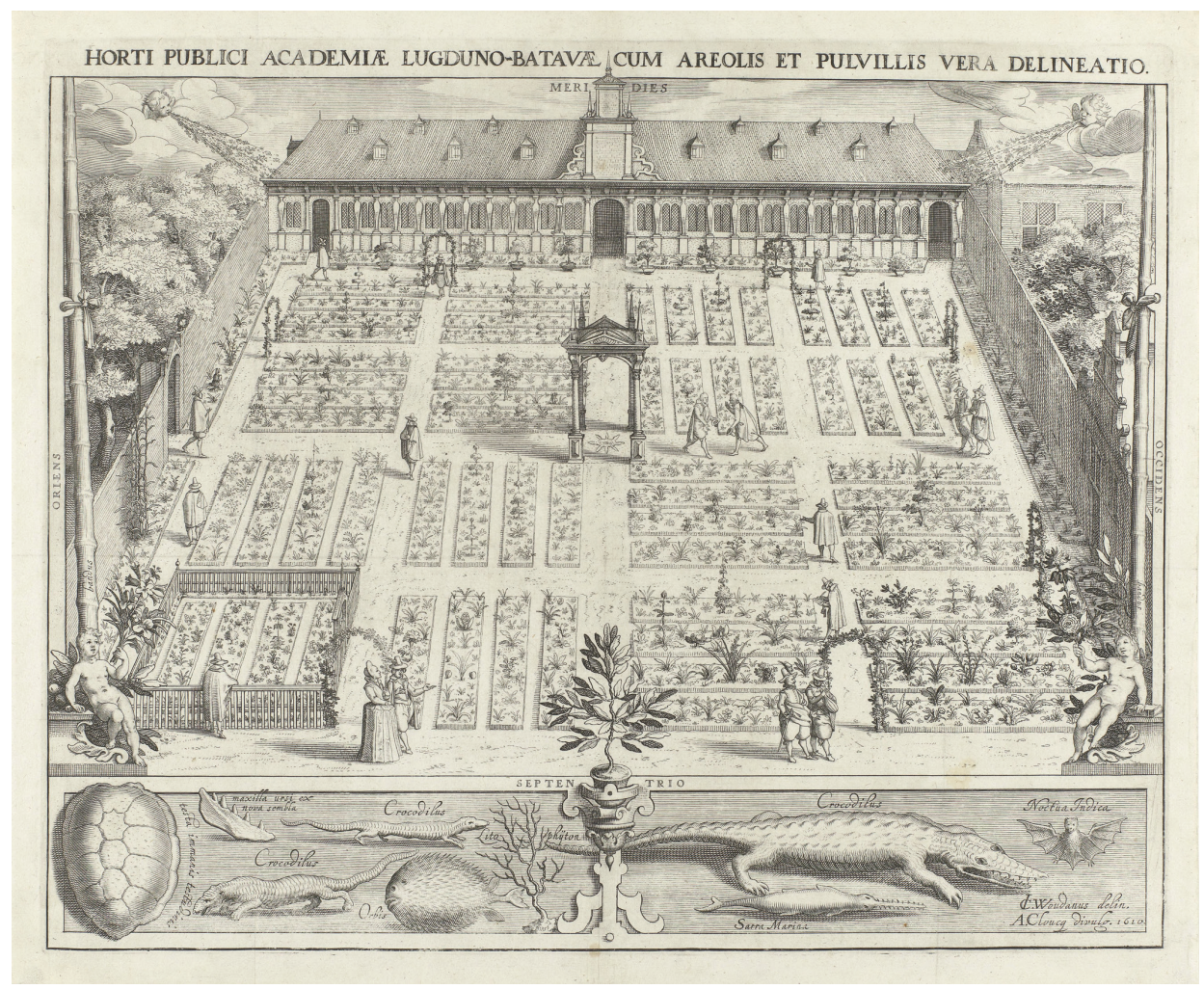

Fig. 3 Willem Isaacsz. Swanenburg (after Jan Cornelisz. Woudanus), Hortus Botanicus of the University of Leiden, 1610, engraving, 32,8 $\times$ 40,4 cm, Amsterdam, Rijksmuseum.

In practice, however, there remained obstacles in the participation of women in the public sphere of botany. A lack of formal education, and thus also a lack of Latin, the 'universal tongue' of scientific enquiry, when combined with the the inaccessibility of formal institutions, could create particularly strong barriers.

The best known and most celebrated Dutch liefhebbers, botanists, and other 'scientists' of the seventeenth century tended to belong to one or more of the following associations or civic groups: academia; the Royal Society in London; the Dutch East and West India companies (voc and wIC, respectively); the wealthy merchant elite, and civic office. ${ }^{26}$ Cuper, for example, was a professor of classics at the Athenaeum Illustre of Deventer, a delegate of the States-General, and a member of the Institut de France and the Académie des inscriptions et des belles-lettres, while Witsen was university-educated, held several civic offices including the mayorship of Amsterdam, and was a director of the voc and

26 The term 'scientist' is used here anachronistically to describe a broad category of individuals which, during the seventeenth century, would have included mathematicians, botanists, and natural philosophers, amongst others. 


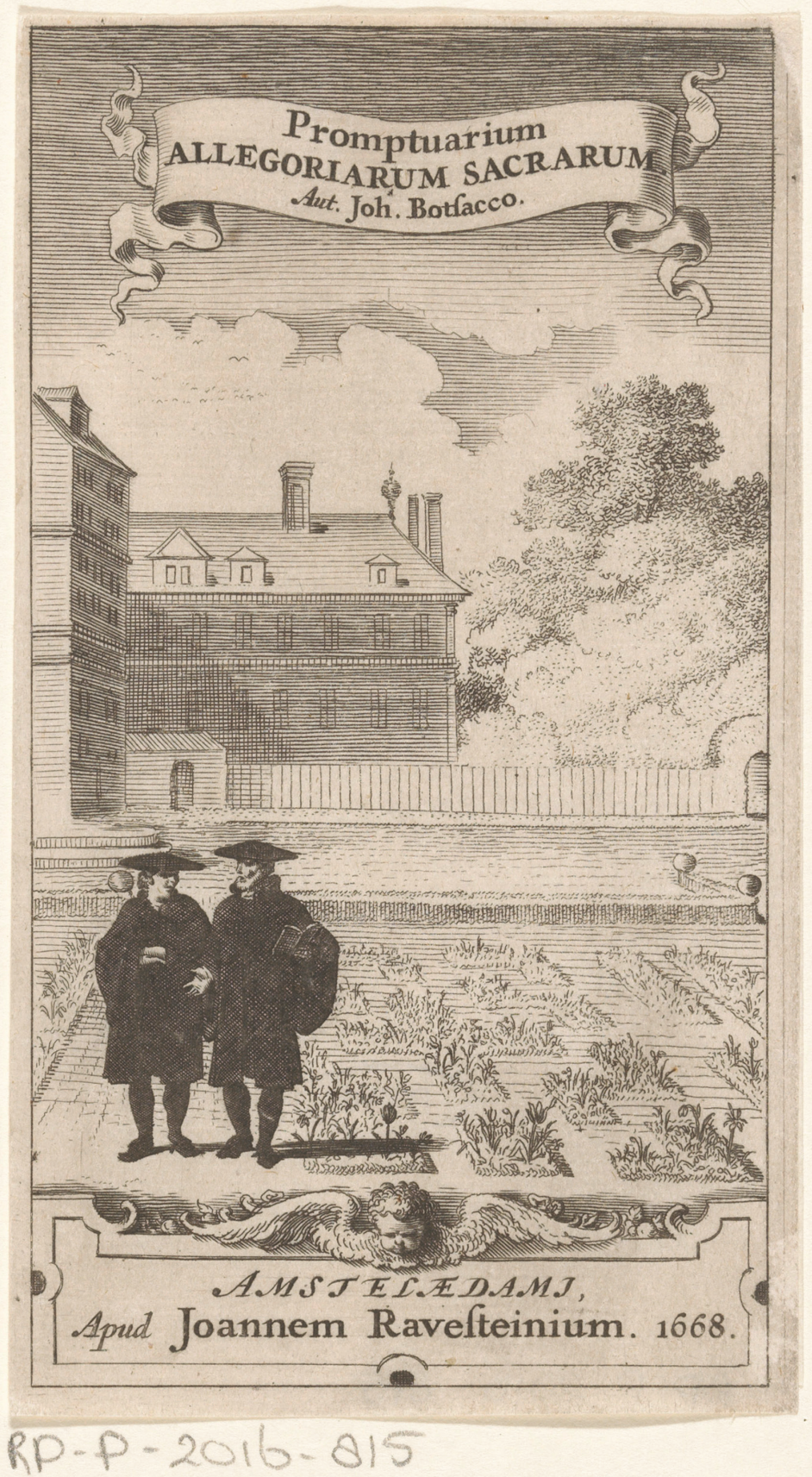

Fig. 4 Pieter Holsteyn II (probably), Academics in a garden, 1668, engraving, 14,4 $x 8,1 \mathrm{~cm}$, Amsterdam, Rijksmuseum. 


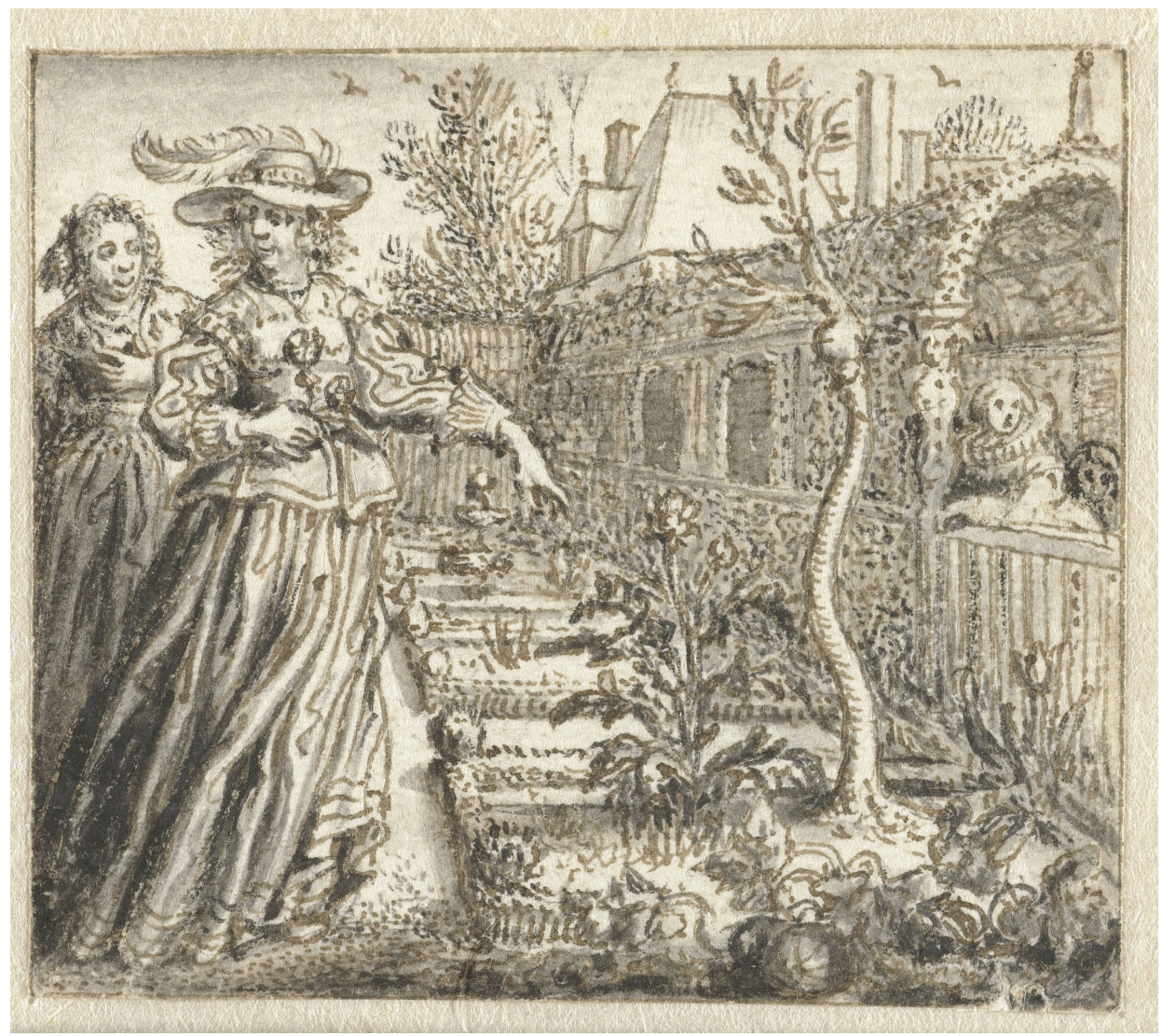

Fig. 5 Adriaen Pietersz. van de Venne, Women in a garden, 1629-1634, pen in brown, brush in grey, $5 x 5,5 \mathrm{~cm}$, Amsterdam, Rijksmuseum.

member of the Royal Society. ${ }^{27}$ These were the most influential institutions to which they could belong or in which they could hold an interest. From the middle of the seventeenth century onwards, institutions, particularly academies and universities, functioned as 'distinct communal groups' that shaped the public sphere of natural knowledge. Above all, formal institutions conferred upon their members the imprimatur of prestige, and trustworthiness.

Importantly, formal institutions influenced the creation of knowledge and ways of thinking. Members determined what questions warranted investigation and suggested what experiments ought to be carried out. The networks and sources of information and knowledge these institutions provided were key to the establishment of a professional reputation, the deployment of influence, the acquisition of valuable rarities, and success. It 
is in participating in these networks that they could share discoveries, debate the value of various hypotheses, and create knowledge - more often than not in Latin.

Participation in the public discourse of natural knowledge was theoretically open to individuals of all classes, although fees and dues put membership out of reach for those of modest means. ${ }^{28}$ The learned elite frequently relied upon the practical knowledge imparted by those with practical experience, such as fishermen and midwives. Formal institutions, however, were strictly male, at least in the Dutch Republic, France, and England: there was no amount of money, intelligence, or aristocratic rank that would see a woman accepted as a member. ${ }^{29}$ It was not until 1925 that the Royal Society agreed that women could be admitted as members and a further twenty years before any women were in fact elected as such. ${ }^{30}$ In northern Europe, early modern women were precluded from entering university. ${ }^{31}$ For every man, such as François Poullain de la Barre (1647-1723), who argued that the mind has no sex and championed social equality for women, or Johan van Beverwijck (1594-1647), who claimed that women were in fact superior to men, the status quo was that most authors argued that women did not possess the necessary abilities for science and advanced knowledge, a situation supported by the English natural philosopher Margaret Cavendish (1623-1673), who wrote that women were naturally inferior to and weaker than men. ${ }^{32}$

Thus, in practice, women could seldom participate in the formal structures for the creation of knowledge for public consumption or enter the public discourse of natural knowledge, at least not directly. ${ }^{33}$ As the creation and validation of natural knowledge became increasingly institutionalised through academies and universities during the course of the seventeenth century, women found themselves on the periphery. As Martha Howell remarked, 'women might be tolerated in an economic, social or cultural space occupied by men, but if that space was powerful enough to confer honour on men, women were both discursively and in practice marginalised in it'. ${ }^{34}$ This is not to say, however, that women did not participate indirectly in or otherwise contribute to the public sphere of natural knowledge. ${ }^{35}$ According to Londa Schiebinger, 'women in princely courts and

28 Sprat, History of the Royal Society of London, 62-68, 72.

29 An often-told story is that Margaret Cavendish (1623-1673), then a published natural philosopher and patron of Cambridge University, only succeeded in attending a meeting of the Royal Society in London after an insistent request and 'after much debate pro and con': Pepys, The Diary of Samuel Pepys, viII, 243.

30 Ferry, 'The exception and the rule'. It took the Académie des Sciences (known as the Académie Royale des Sciences until 1816) in Paris until 1979 to elect a woman: Schiebinger, The Mind has no Sex, 2. Women were accepted in several academies in Italy, however: Schiebinger, 'Women of Natural Knowledge', 197-198.

31 Note that this was not necessarily the case in the Italian states, where women played an important role in the development of science and cultural institutions: Findlen, 'A forgotten Newtonian'. For a discussion on the relationship between women and learned institutions, see Labalme, Beyond Their Sex; Larsen, Star of Utrecht, 13-18.

32 Poullain de la Barre, De l'Egalité des deux sexes; Van Beverwijck, Van de Wtnementheyt des Vrouwelijcken Geslachts; Cavendish, The Worlds Olio. See also Niekus Moore, 'Not by Nature but by Custom'. For a nuanced interpretation of Cavendish's position on women and gender, see Boyle, 'Margaret Cavendish on Gender'.

33 Schiebinger, 'Women of Natural Knowledge', 194.

34 Howell, 'Michaelina Wautier', 101.

35 James Petiver, Musei Petiveriani, 96. 
the informal scientific circles that emerged from them served as important patrons, interlocutors, hostesses, and ready consumers of natural knowledge and curiosities' ${ }^{36}$ In other words, women mostly served in a supporting role; important, but increasingly peripheral. Without the reliance on the exchange of information, creation of knowledge, network of contacts (and thus consumers and disseminators of knowledge), and implicit seal of legitimacy and approval automatically offered by formal institutions, women were at a distinct disadvantage when it came to their direct participation as anything other than facilitators in the creation and dissemination of natural knowledge.

\section{Locating Block's Botanical Networks in Print}

The role of the written word - from manuscripts to print publications - in the facilitation of exchanges and in the existence and survival of the public sphere of natural knowledge cannot be underestimated. In the seventeenth century in particular, books, journals, newspapers, and pamphlets could be produced relatively inexpensively (depending on the quantity and quality of illustrations, a relevant consideration for botany) and they were available widely. Publications on botanical gardens flourished during the seventeenth century, particularly in the Dutch Republic. ${ }^{37}$ In the Leiden and Amsterdam gardens, inventory was constantly in flux, thus necessitating the production of print catalogues in 'strikingly large numbers'.$^{38}$ Presumably, these publications were relied upon by serious liefhebbers and professional botanists, who required frequently updated inventories of the Republic's two most highly reputed gardens. From Block's correspondence with the Italian professor of botany Lelio Trionfetti (1647-1722) we learn that she also amassed a large collection of books, especially those concerning botany. ${ }^{39}$ Her library was so great, according to her nephew Gualtherus Blok, that it betrayed in her a 'masculine spirit'. ${ }^{\circ}$

Print expanded the opportunities available for individuals to participate in the shaping of public opinion. It was also key, together with experimental science, in explaining how public opinion acquired its social authority. The overarching philosophy of experimental science was that advances required critical and open debate in a public forum; that forum was provided by the print media. ${ }^{41}$ The Philosophical Transactions of the Royal Society, first published in 1665 , exemplify the role of print in the facilitation of public discourse in

36 Schiebinger, 'Women of Natural Knowledge', 194.

37 Feuerstein-Herz, 'Garten und Buch', 93-97, notes that there existed twenty-five publications concerning seven botanical gardens in the Low Countries between 1601-1700, the highest ratio of the countries she surveyed. This compares to eighteen publications for nine botanical gardens in Italy, and twenty-eight publications for nine gardens in France.

38 Feuerstein-Herz, 'Garten und Buch', 105.

39 See for example Block to Trionfetti, Amsterdam, 28 February 1687, in Poelhekke and Oomen, Elf brieven van Agnes Block, 14-15.

40 Blok, Vyver-Hof, 7. 'De Boek-saal eindelyk bint ons wel allermeest; / Hier toont gy wys-beleid, een mannelyke geest'. Unless otherwise noted, translations from the Dutch are mine.

41 Zaret, 'Religion, Science, and Printing', 218, 227-228. Zaret was concerned with early modern England, but his conclusion is equally applicable to the Dutch Republic. 
the advancement of natural knowledge. The Transactions encapsulate the objectives of the public sphere: the sharing, debating, creating, and disseminating of natural knowledge. In publishing proceedings, letters, and commentaries, the Philosophical Transactions promoted discussion, validation, and refutation. Appearing as an author in the Philosophical Transactions, or even being mentioned in the publication, offered a tacit seal of approval by and of good reputation in the eyes of its members..$^{42}$ Furthermore, print media served as a 'meeting place', where creators and consumers of natural knowledge gathered to confer. In the words of Leah Knight, 'early modern book[s] about plants also embedded a matrix of information about a community in formation. That community was not situated in any single geographic site, nor did it meet at regular intervals: instead, it found its being at the nexus of plants and texts about them. ${ }^{43}$ And while authors in that community were almost exclusively male, this did not necessarily preclude women's participation. ${ }^{44}$

As far as is known, Block did not publish a treatise or a catalogue of her garden. ${ }^{45}$ Many others, however, did. Did they know of Block? What did they think of her? To the extent that Block was present in the print publications that contributed to the discussion and evolution of knowledge of botany, I argue that she did participate in that public sphere. While this may have been through the agency of men, it remains that the treatises convey information about Block and her influence, about her knowledge, and about the ways in which she shared it. Through inclusion in internationally renowned treatises, Block received recognition and legitimacy as an amateur botanist, an ambition she signalled through the commission of the Weenix portrait and through the distribution of a portrait medal portraying her as Flora Batava (fig. 6).

A comprehensive search of botanical catalogues and treatises dating from the seventeenth century, focusing on the period between 1670 and 1704 - an approximation of the years in which Block was active at Vijverhof - reveals that the higher echelons of public discourse on botany were populated by a relatively small group of men. With remarkable consistency, the catalogues and treatises cite the same core works and praise the knowledge and generosity in contributing rare plant specimens by the same, small cast of characters. I conclude that the more frequently an individual is referred to in print, the more likely it is that this individual is a respected expert and/or contributor to the field of botany. Adjusting for the relevant time period, the most prominent contributors to the development of botany during Block's prime years of activity numbered twenty-two. They were located in the Low Countries, Poland, England and Scotland, Germany, France, and Dutch Malabar. ${ }^{46}$ The published works of this group clearly show that many of them were part of Block's own network.

42 Zaret, 'Religion, Science, and Printing', 230-231.

43 Knight, 'Horticultural networking', 76.

44 A case in point is Maria Sibylla Merian, who achieved success as a naturalist and artist. She is known today amongst other things for her book Metamorphosis Insectorum Surinamensium (1705).

45 We know that a catalogue detailing the contents of her estate was prepared after her death, based on advertisements that appeared in the local press in July 1704. See for example the Extraordinaire Haerlemse Donderdaegse Courant 30 (1704). No copies of this catalogue appear to have survived.

46 Eleven of the twenty-two individuals lived in the Dutch Republic: Jan Commelin; Caspar Commelin; Simon Schijnvoet; Levinus Vincent; Petrus Hotton; Frederik Ruysch; Paul Hermann; Henri D’Acquet; Nicolaas 

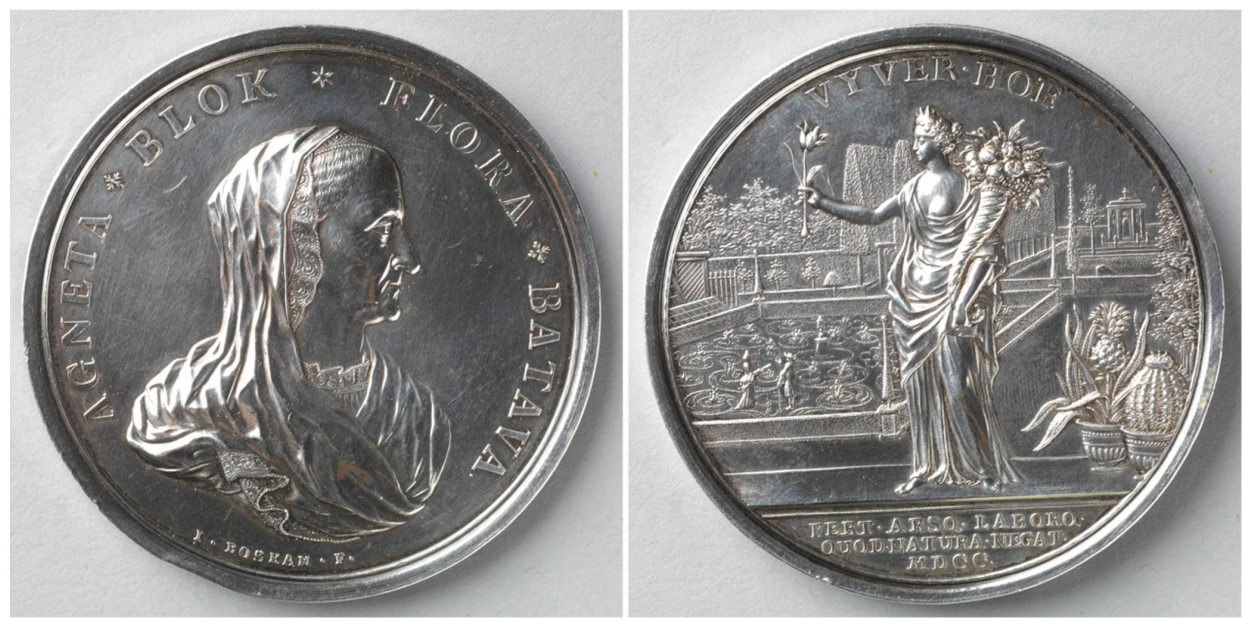

Fig. 6 Jan Boskam, Portrait medal of Agneta Blok as Flora Batava, 17oo, silver, $6 \mathrm{~cm}$, Utrecht, Centraal Museum.

The first reference to Block in print dates to 1687 , or slightly more than one decade after she was able to devote herself to the development of Vijverhof, if one takes into consideration the disruption brought about by the Year of Disaster of 1672, which wrought significant destruction to the area around Utrecht, including the region along the River Vecht. The reference is contained in Paul Hermann's Horti academici Lugduno-Batavi catalogus. Hermann (1646-1695) was the director of the botanical garden at Leiden. Prior to assuming that role, he had served as a medical officer for the voc and taken the opportunity to explore and observe the flora of Ceylon. ${ }^{47}$ Block is the only woman included in his catalogue. She appears three times:

Auricula ursi lutea: [...] Mr Ciassi sent this from Venice to the most respectable Mrs Agnita de Block, who in her generosity gave it to me.

Aster Americanus latifolius maximus puniceis caulibus. [...] Mrs Agnita de Block, highly versed in botany, sent this aster to me.

Crotalaria Asiatica trifolia subhirsuta Ann. [...] I recently came upon the fifth species of the crotalaria in the garden of the most respectable Mrs de Block..$^{48}$

Hermann associates Block directly with plant specimens, which would have suggested to a reader that she knew the species in her possession and appreciated their rarity.

Witsen; Joan Huydecoper; and Abraham Munting. The next largest contingent resided in England: Hans Sloane; William Sherard; John Ray; James Petiver; Martin Lister; and Leonard Plukenet. Robert Morrison lived in Scotland, Hendrik van Rheede tot Drakenstein in Dutch Malabar, Jacob Breyne in Poland, Joseph Pitton de Tournefort in France, and Johan Georg Volkamer in Germany.

47 Andel et al., 'Possible Rumphius specimens', 11.

48 Hermann, Horti Academici, 82, 652, 663. Unless indicated otherwise, all Latin translations are by Dr. Corinna Vermeulen. 
His description of Block as respectable and highly versed in botany would have signalled to readers that Block was more than a mere dilettante. Hermann confirms that he visited Block's garden recently, and the entry suggests that he may have even been a regular visitor. It is likely that he had a good relationship with her. Certainly, her inclusion in a book written in Latin, and therefore for consumption by educated individuals, placed Block within the realm of the learned.

A mere two years after the publication of Hermann's Horti Academici, the English botanist William Sherard published his aggregation and summary of the works of Hermann and of the French botanist Joseph Pitton de Tournefort (1656-1708). In the preface to Schola Botanica Sive Catalogus Plantarum, Sherard writes:

For when during my stay in the Low Countries last summer I paid a few visits to the more famous gardens of the Dutch - those of the gentlemen the Prince of Orange, Bentinck, Van Beverningk, Fagel, Beaumont, Maresius, Flinius, Riedt, and the ladies De Block and Poulle, and the public gardens at Leiden and Amsterdam - and inspected the plants that were grown there, striking for their rarity as well as their beauty. ${ }^{49}$

In Sherard's list, Block is in the company of the 'greats', such as the 1st Earl of Portland, diplomat and amateur botanist Willem Bentinck (1649-1709), and Grand Pensionary and amateur botanist Gaspar Fagel (1634-1688). Also included in the list is Block's nephew and Amsterdam neighbour, Philips de Flines (1640-1700), who kept a country estate in the region of Haarlem and who also cultivated rare and exotic plants and trees. Sherard mentions another woman, the owner of the country estate Gunterstein and Block's neighbour in the country side, Magdalena Poulle (1632-1699)..$^{50}$ What the reader takes away from Sherard's preface is that Block is in the company of the most celebrated amateur botanists and her garden, like the public gardens of Leiden and Amsterdam, is worthy of attention. Critically, the preface confirms that Sherard was a visitor to Vijverhof and had presumably experienced Block's skills as a botanist for himself. In an empirical world in which first-hand observation was valued nearly above all else, Sherard's preface thus contained an endorsement, which stood out by being separated from the catalogue entries. ${ }^{51}$ By being included in Sherard's preface, Block's reputation and that of her garden could grow further.

Paul Hermann carried on his work at the Leiden botanical garden until his death in 1695. His last work, Paradisus Batavus, was co-edited by William Sherard and published posthumously in 1698. Paradisus Batavus refers to Block's contributions to the collection of the Leiden botanical garden. With respect to the aster, Hermann writes:

This aster, the seed having been brought in from New England, was first raised by Mistress Agnes de Block, the most excellent wife of the most praised Master Sybrand de Flines, she who was the first cultivator of all the most exotic breeds and most studious investigator without rival, by whose outstanding liberality it crosses later into the gardens of others. ${ }^{52}$

49 Sherard, Schola Botanica Sive Catalogus Plantarum, preface.

50 On Magdanela Poulle's presence in the world of botany, see Zwaan, 'Magdalena Poulle'.

51 Ogilvie, The Science of Describing, 12-13, describes this preoccupation as the 'early modern European cult of the fact'.

52 Hermann, Paradisus Batavus, 95-99. Translation by Harriet Tupper. Emphasis added. 
The description of Block as a 'first cultivator' and 'studious investigator' is remarkable. Whereas earlier descriptions as 'honest' or 'respectable' might have been seen as merely polite (or even as the type of gendered trope found in contemporary texts), the characterisation of Block's work as cultivation and investigation brings her within the ambit of the 'garden as experimental laboratory'. It is possible to interpret Hermann's use of language as raising Block nearer the category of 'equals' in the botanical discourse.

There is much else we can reasonably infer from this entry, including that Block was knowledgeable about plants and specimens, that she knew how to obtain seeds from abroad for the most exotic species, and that she was technically knowledgeable, as she knew how to grow these exotic plants and flowers in the difficult climate of the Dutch Republic. Furthermore, Hermann confirms that Block provided species to the Leiden botanical garden, then the most respected academic garden in the Republic, thereby acknowledging Block's access to the higher ranks of botany and, consequently, her influence.

The impact of the Hermann's entry on Block is even greater when one considers the following book review, authored by English naturalist and Royal Society member John Ray (1627-1705), which appeared in the Philosophical Transactions in 1699:

The learned and much celebrated Herbalist Dr. Paul Hermans, Author of this Work, whose Name alone is sufficient to recommend it to the ingenious Reader, designed therein to give us the History of such rare and non-descript Plants, as well European as Indian, as were cultivated either in publick Physick-Gardens, or those of private curious Persons, in and about Holland; as we see now accordingly performed. [...] All that I shall or need say of this Piece is, That the Descriptions are very accurate, and sufficient alone to lead us into a certain and unerring Knowledge of the Plants described, and withal concise, and not encumbered with superfluous and unnecessary Stuff, which obscures rather than illustrates..$^{33}$

The language used by Ray in his review is powerful. Not only was Block associated through print with a renowned and highly-reputable botanist, 'whose Name alone' suffices in conferring legitimacy, but she had been strongly praised by him. The knowledge Block possessed and shared indirectly and implicitly received the approval of John Ray and of the Royal Society.

\section{Visitors and Clients}

The 1702 poem Vyver-Hof by Gualtherus Blok includes the lines 'while we walk, through dense hedgerows $[\ldots]$ so you come, kindly, to catch up with your guests'..$^{54}$ Although she did not leave behind any records of visits to her estate nor a diary documenting her friendships and collaborations, we know that Block guided guests through her garden. In addition to Hermann and Sherard, Block entertained the Polish merchant, naturalist, artist, and enthusiastic plant collector Jacob Breyne (1637-1697) at Vijverhof. Breyne made several trips to the Low Countries in the pursuit of specimens,

53 The Royal Society, Philosophical Transactions 21 (31 December 1699) 63-67. Emphasis added.

54 Blok, Vyver-Hof, 5: 'Terwyl wy wandelen, door digte Haagen [...] So komt gy, vriendelyk, uw gasten in te haalen.' 
becoming a close associate of the most noted botanists and collectors in the early modern Dutch Republic, including Paul Hermann, the director of the Amsterdam hortus medicus Jan Commelin (1629-1692), and the regent, diplomat, and amateur botanist Hieronymus van Beverningh (1614-1690). ${ }^{55}$ A probable scenario is that one of the noted liefhebbers and botanists with whom Breyne had become friends introduced him to Block and Vijverhof. We know from her letters to Trionfetti in Bologna that Block claimed to be in frequent contact with Hermann, and we know that Hermann was a visitor to Vijverhof. ${ }^{56} \mathrm{He}$ might have been the one to accompany Breyne to Loenen aan de Vecht.

Breyne published extensively on botany. ${ }^{57}$ In 1680 and 1689 , he published the two-volume Prodromus fasciculi rariorum plantarum in Hortis Hollandiae, which he dedicated to Van Beverningh. Breyne writes that he was fortunate to see so many rare plants during his travels to the Dutch Republic - in fact, he is certain that he has forgotten many, and that many others have since grown..$^{58}$ One of the few garden owners he singles out is none other than Agnes Block, the only woman to whom he refers. Her name appears no fewer than thirteen times - nearly double the number of mentions of her nephew, Philips de Flines. ${ }^{59}$ Two sample entries are as follows:

EUPATORIUM: [...] In the garden, very rich in exotic plants, of the most respectable and famous Mrs Agneta van den Block, our Botanic Sibyl, faithful wife of Mr Sybrand de Flines, a famous merchant in Amsterdam; she is famous for her wisdom as well as her piety and her honourable life. ${ }^{60}$

HYACINTHUS: [...] I only saw it in the garden of the brilliant Mrs de Flines, with my own eyes and the greatest $_{\text {pleasure. }}{ }^{61}$

Once again, Block is characterised by her fame and respectability, but also as a Sibyl a prophetess of botany. Unlike the language used by Hermann and Sherard, however, Breyne makes a point of mentioning Block's faithfulness as a spouse, her piety, and her 'honourable life'. This is markedly different from the language used by Breyne with respect to plant specimens observed in the public gardens and the gardens of men, where the owners and curators are described either as 'learned', and 'distinguished', or requiring no qualifier, in the case of Philips de Flines:

MARRUBIUM: [...] The seeds of this plant were first sent to me by the learned Mr Tournefort, and later I shared them with the distinguished Mr Commelin. ${ }^{62}$

MIMOSA: [...] With flowers and ripe pods in the garden of Mr Philips de Flines. Mr Kiggelar gave me a pod of this mimosa with the name Wattepena. ${ }^{63}$

55 For more on van Beverningh, see Fleischer, 'Gardening Nature, Gardening Knowledge'.

56 Block to Trionfetti, Amsterdam (?), c. 1687-1688, in Poelhekke and Oomen, Elf brieven van Agnes Block, 16.

57 Fleischer discusses Breyne's production of botanical books and confirms that his network included Hermann and James Petiver, amongst others: Fleischer, 'Gardening Nature, Gardening Knowledge', 294-296.

58 Jacob Breyne, Prodromi fasiculi rariorum plantarum secundus, 108.

59 Breyne, Prodromus Secundus, 61, 62, 64, 69, 72, 76, 84, 95, 100, 104, 108.

60 Breyne, Prodromus Secundus, 61-62.

61 Breyne, Prodromus Secundus, 72.

62 Breyne, Prodromus Secundus, 78.

63 Breyne, Prodromus Secundus, 83. 
Breyne does not appear ready or willing to see Block in a realm that is completely divorced from the domestic context that formed the bedrock of social gender expectations. Even if this were intended positively by Breyne, the language he uses nevertheless reinforces the gendered tropes of the period by focusing on Block's piety and on her role as a devoted wide. Notwithstanding the gendered language, however, Breyne's praise is a testament to Block's knowledge and expertise.

Block was also highly respected by the director of the Amsterdam hortus medicus, Caspar Commelin (1668-1731). Commelin, a physician and botanist, succeeded his uncle, Jan Commelin, to the post in 1696. Commelin first included Block in his 1701 Horti Medici Amstelaedamensis, which expanded upon Jan Commelin's text of the same name, dating to 1697. In 1706, after Block's death, he would also be named professor of botany at the Athenaeum Illustre of Amsterdam. Horti Medici Amstelodamensis was Commelin's most influential publication. He chose to have the book included in the 1724 portrait of the Inspectors of the Medical College, by Cornelis Troost, a strong indication by Commelin of the importance he accorded to this work.

Horti Medici Amstelodamensis contains a list of the plants in the medical garden of Amsterdam. For the rarest and most exotic specimens, he gives a detailed description including their provenance. For Tithymalus Aizoides Arbor Caudice Angulari Nerii Folio (a type of succulent), Commelin writes:

I was given this plant by the most respectable and brilliant Mrs Agneta de Block, the Botanic Sibyl of our time, widow of Mr Sybrand de Flines. She received it from Ambon and kept it in her greenhouse for some years; she has this greenhouse, abundant in every kind of plant both exotic and indigenous, on the bank of the river Vecht. ${ }^{64}$

This same reference to Agnes Block is repeated in Commelin's 1703 Praeludia Botanica. In both the Horti Medici and the Praeludia Botanica, Block is the only woman to be included.

Once again, it is possible to infer from this entry that Block was knowledgeable about the nature of plants and exotic specimens; she knew what they were, and how to cultivate them. Commelin also confirms that Block had a greenhouse, and therefore possessed the latest botanical technology. Significantly, Commelin tells us that Block had established contacts abroad which allowed her to import exotic plants that were not even available to the public gardens of Leiden and Amsterdam. This entry demonstrates how Block could use her contacts to obtain rare plants, and trade them with experts such as Commelin and Hermann. In exchange, Block might have hoped to receive other plants, knowledge, and publicity.

Block's experience was clearly valued by those in charge of the two most important academic gardens at the end of the seventeenth century in the Dutch Republic, namely the Leiden botanical garden and the Amsterdam medical garden. Lukas Rieppel argues that 'the credibility and status of natural knowledge has always been bound up with that of the sites in which it is produced and displayed'. Block's botanical knowledge and the richness of her garden were linked through print with the Leiden botanical garden and the Amsterdam medical garden. Following's Rieppel's argument, Block's reputation and credibility would have ranked highly in the public sphere of botany of the late seventeenth century. ${ }^{65}$

64 Commelin, Praeludia Botanica, 56.

65 Rieppel, 'Museums and Botanical Gardens'. 


\section{Conclusion}

The early modern public sphere of botany in print had the advantages of longevity and unbound mobility. The treatises through which Block participated in the public sphere outlived her and circulated internationally, recording and spreading her contributions to the discourse. Block herself sent a copy of Hermann's Horti Academici and Paradisus Batavus to Lelio Trionfetti in Bologna. ${ }^{66}$ As the books were referred to in the treatises by James Petiver and Robert Morrison, we know that they also circulated in England. Even when not mentioned, Block is arguably incorporated by reference when authors repeatedly refer their readers to the treatises by Hermann, Sherard, Breyne, and Commelin. Indeed, every time a reader wishes to follow up on an entry and is directed to Hermann's treatise, for example, the entries in that treatise that incorporate Block may be discovered anew. As the influence of these treatises continued throughout the years that followed, Block's contribution remained alive. In 1708, the physicist Emanuel König (1658-1731), of the University of Basel, produced a four-volume Regnum Vegetabile, Physice, Medice, Anatomice, Chymice, Theoretice, Practice, which he dedicated to the Swiss mathematician Johann Bernoulli (1667-1748), amongst others. König listed all the species of Tithymalus that had been identified to that point. For Tithymalus Aizoides Arbor Caudice Angulari Nerii Folio, he referred his reader to Commelin's Praeludia Botanica. ${ }^{67}$ The reader who followed up would have read the following:

I was given this plant by the most respectable and brilliant Mrs Agneta de Block, the Botanic Sibyl of our time, widow of Mr Sybrand de Flines. She received it from Ambon and kept it in her greenhouse for some years; she has this greenhouse, abundant in every kind of plant both exotic and indigenous, on the bank of the river Vecht. ${ }^{68}$

Block was a knowledgeable and experienced botanist, and she was recognised as such. In her circle, we might even say that she was famous. Expert botanists from Holland but also Poland and England came to visit Vijverhof. We can infer that Block would have acquired part of her knowledge on botany based on discussions and exchanges she had with these experts. The entries in the treatises authored by Hermann, Sherard, Breyne, and Commelin provide evidence that Block knew how to obtain rare plant specimens and cultivate them. They also confirm that she had built durable relationships with leading experts in the field. The treatises also demonstrate how Block shared her expertise: by generously giving and exchanging seeds and cuttings with other garden owners, and by remaining highly visible in their publications. Hermann, Sherard, Breyne, and Commelin included Block in their treatises to honour her labour and knowledge, and to express gratitude. They may have also wished to continue to secure her patronage; if Block had not been reliably knowledgeable, however, they would not have discussed her contributions so extensively. Above all, what Knight refers to as a practice of 'social citation' was 'a record of the community' that made the works of the authors possible. ${ }^{69}$

66 Block to Trionfetti, Amsterdam, 28 February 1667, in Poelhekke and Oomen, Elf brieven van Agnes Block, 14-15.

67 König, Regnum Vegetabile, 523.

68 Commelin, Praeludia Botanica, 56.

69 Knight, 'Horticultural networking', 64. 
The botanical network to which Block belonged was both process and evidence. It provided the mechanism through which, in the absence of direct access to formal institutions, Block acquired, shared, and disseminated botanical knowledge and elevated and/or legitimised her reputation as an amateur botanist. The printed record left behind by the treatises serves as evidence that the network existed and that Block was undeniably part of it. Through this network, Block was influential in the public sphere of botany.

This case study also highlights the necessity of re-thinking how we approach early modern women; of adapting our research methodologies and analytical frameworks in order to better understand the stories of early modern women and their contributions to public life and culture. Using a traditional, monograph-based approach to the study of Agnes Block, one might have reasonably concluded that she was a dilettante with a garden: a wealthy matron who devoted enormous amounts of time and money to her garden, but about whom little is known. Indeed, searching for 'Agnes Block' in database of the Amsterdam municipal archives yields a number of testaments, but little else. ${ }^{70} \mathrm{~A}$ key in responding to the challenges posed by the archives is to interrogate primary and secondary sources differently. ${ }^{71}$ Although her voice was at times mediated through men, Block was an influential figure in the public sphere of botany and she actively participated in the creation, exchange, and dissemination of botanical knowledge. She is indelibly associated with the luminaries of her time in print - something that was achievable only through her participation in informal networks.

\section{Bibliography}

Abrahamse, Jaap Evert, Metropolis in the Making. A Planning History of Amsterdam in the Dutch Golden Age (Turnhout 2019).

Andel, T.R. van, et al., 'Possible Rumphius specimens detected in Paul Hermann's Ceylon herbarium (1672-1679) in Leiden, The Netherlands', Blumea. Biodiversity, Evolution and Biogeography of Plants 63 (2018/1) 11-19.

Avery, Victoria, and Melissa Calaresu (eds.), Feast \& Fast. The Art of Food in Europe 1500-180o (Cambridge 2019).

Backer, Anne Mieke, Er stond een vrouw in de tuin. Over de rol van vrouwen in het Nederlandse landschap (Rotterdam 2016).

Baldassari, Fabrizio, 'Introduction. Gardens as Laboratories. A History of Botanical Sciences?', Journal of Early Modern Studies 6 (2017/1) 9-19.

Beverwijck, Johan van, Van de Wtnementheyt des Vrouwelijcken Geslachts (Dordrecht: Hendrick van Esch, 2nd ed. 1643).

Block, Gualtherus, Vyver-hof van Agneta Blok (Amsterdam 1702).

Blouin, Francis X., and William G. Rosenberg, Processing the Past. Contesting Authority in History and the Archives (Oxford 2011).

70 One can find some information about Agnes Block in the archives of the family de Flines: see for example sA, Archief Familie de Flines, 131, Jacob de Flines, Family chronicle 1679-1713.

71 Concerns regarding the structural bias of the archives have been noted, particularly in the past decade. See for example Blouin and Rosenberg, Processing the Past; Blouin and Rosenberg, Archives, Documentation, and Institutions of Social Memory. See also Head, 'Documents, Archives, and Proof around 1700', 929. 
Blouin, Francis X., and William G. Rosenberg, Archives, Documentation, and Institutions of Social Memory (Ann Arbor 2005).

Boyle, Deborah, 'Margaret Cavendish on Gender, Nature, and Freedom', Hypathia 28 (2013/3) 516-532.

Breyne, Jacob, Prodromi fasciculi rariorum plantarum primus et secundus, quondam separatim, nunc nova hac editiones multum desiderata coniunctim editi, notulisque illustrati. Accedunt icones rariorum et exoticarum plantarum aeri incisae, fasciculo olim promisso destinatae: adiectis nominibus et succinctis descriptionibus. (Gdansk: Thom. Joh. Schreiberi, 1739).

Cavendish, Margaret, The Worlds Olio (London: J. Martin, 1655).

Chen, Bianca, 'Digging for Antiquities with Diplomats. Gisbert Cuper (1644-1716) and his Social Capital', Republics of Letters 1 (2009/1).

Commelin, Caspar, et al., Horti medici Amstelodamensis rariorum tam Orientalis, quam Occidentalis Indiae: aliarumque peregrinarum plantarum magno studio ac labore, sumptibus civitatis Amstelodamensis, longa annorum serie collectarum, descriptio et icones ad vivum aeri incisae (Leiden: Frederik Haringh, 1701).

Commelin, Caspar, Caspari Commelin Praeludia botanica ad publicas plantarum exoticarum demonstrations, dicta in Horto Medico (Leiden: Frederik Haringh, 1703).

Cook, Harold John, Matters of Exchange. Commerce, Medicine, and Science in the Dutch Golden Age (New Haven 2008).

Cuperus, Gijsbert, Lettres de critique, de litterature, d'histoire, \& $c$ c. ecrites a divers savans de l'Europe, par feu monsieur Gisbert Cuper (Amsterdam: Johann Caspar Arkstee and Leipzig: Henricus Merkus, 1755).

Curry, Anne et al., (eds.), Worlds of Natural History (Cambridge 2018).

Davis, Natalie Zemon, Women on the Margins. Three Seventeenth-Century Lives (Cambridge 1995).

Egmond, Florike. The World of Carolus Clusius. Natural History in the Making, 1550-1610 (London 2010).

Ferry, Georgina, 'The exception and the rule. Women and the Royal Society 1945-2010', Notes \& Records of The Royal Society 64 (2010) 163-172.

Feuerstein-Herz, Petra, 'Garten und Buch zur Repräsentation der europäischen botanischen Gärten im Buchdruck des 16. Bis 18. Jahrhunderts', in Ingrid Kästner and Jürgen Kiefer (eds.), Botanische Gärten und botanische Forschungsreisen (Aachen 2011) 93-112.

Findlen, Paula, 'A forgotten Newtonian. Women and Science in the Italian Provinces', in William Clark, Jan Golinski, and Simon Schaffer (eds.), The Sciences in Enlightened Europe (Chicago and London 1999) 313-349.

Findlen, Paula, 'Anatomy Theaters, Botanical Gardens, and Natural History Collections', in Katherine Park and Lorraine Daston (eds.), The Cambridge History of Science. Early Modern Science (New York 2016) 272-290.

Fleischer, Alette, 'Gardening Nature, Gardening Knowledge. The Parallel Activities of Stabilizing Knowledge and Gardens in the Early Modern Period', in Hubertus Fischer, Volker R. Remmert, and Joachim Wolsche-Bulmahn (eds.), Gardens, Knowledge and the Sciences in the Early Modern Period (Basel 2016) 289-304.

Fleischer, Alette, 'The Beemster Polder. Conservative invention and Holland's great pleasure garden, in Lissa Roberts, Simon Schaffer, and Peter Dear (eds.), The Mindful Hand. Inquiry and Invention from the Late Renaissance to Early Industrialisation (Amsterdam 2007) 145-168.

Graft van de, C.C., Agnes Block. Vondels nicht en vriendin (Utrecht 1943).

Gvozdeva, Katja, Tatiana Korneeva, and Kirill Ospovat (eds.), Dramatic Experience. The Poetics of Drama and the Early Modern Public Sphere(s) (Leiden 2017).

Head, Randolph C., 'Documents, Archives, and Proof Around 1700', The Historical Journal 56 (2013/4) 909-930.

Hermann, Paul, Horti academici Lugduno-Batavi catalogus. Exhibens plantarum omnium nomina quibus ab anno 1681 ad annum 1686 hortus fuit instructus ut et plurimam in eodem cultarum et a nemine hucusque editarum descriptiones et icons (Leiden: Boutesteyn, 1687).

Howell, Martha, 'Michaelina Wautier and Working Women in Early-Modern Europe', in Katlijne Van der Stighelen et al., Michaelina Wautier, 1604-1689. Glorifying a Forgotten Talent (Antwerp 2018) 100-119. 
Hunter, Lynette, and Sarah Hutton (eds.), Women, Science, and Medicine. Mothers and Sisters of the Royal Society, 1500-1800 (Phoenix Mill, 1997).

Jong, Erik de, Nature and Art. Dutch Garden and Landscape Architecture, 1650-1740 (Philadelphia 2001).

Jeu, Annelies de, 't Spoor der dichteressen. Netwerken en publicatiemogelijkheden van schrijvende vrouwen in de Republiek (1600-1750) (Hilversum 2000).

Knight, Leah, 'Horticultural Networking and Sociable Citation', in Helen Anne Curry et al. (eds.), Worlds of Natural History (Cambridge 2018) 61-77.

König, Emanuelis, Regnum vegetabile quadripartitum, continens sect. IV (Basel: Emanuelis König, senoris, 1708).

Laarse, Rob van der, 'Amsterdam en Oranje. De politieke cultuur van kasteel en buitenplaats in Hollands Gouden Eeuw', in Yme Kuiper and Ben Olde Meierink (eds.), Buitenplaatsen in de Gouden Eeuw (Hilversum 2015) 66-95.

Labalme, Patricia (ed.), Beyond Their Sex. Learned Women of the European Past (New York 1984).

Larsen, Anne R., Anna Maria van Schurman, 'The Star of Utrecht'. The Educational Vision and Reception of a Savante (Oxford 2016).

Moran, Sarah, and Amanda Pipkin (eds.), Women and Gender in the Early Modern Low Countries, 150o1750 (Leiden 2018).

Niekus Moore, Cornelia, “'Not by Nature but by Custom". Johan van Beverwijck's Van de wtnementheyt des vrouwelicken Geslachts', Sixteenth Century Journal 25 (1994/3): 633-651.

Ogilvie, Brian, The Science of Describing. Natural History in Renaissance Europe (Chicago 2006).

Ogilvie, Sheilagh C. The European Guilds. An Economic Analysis (Princeton 2019).

Ogilvie, Sheilagh C., A Bitter Living. Women, Markets, and Social Capital in Early Modern Germany (Oxford 2010).

Pal, Carol, Republic of Women. Rethinking the Republic of Letters in the Seventeenth Century (Cambridge 2012).

Park, Katharine, and Lorraine Daston (eds.), The Cambridge History of Science. Early Modern Science (Cambridge 2006).

Pepys, Samuel, The Diary of Samuel Pepys. Robert Latham and William Matthews (eds.), 11 vols. (Berkley and Los Angeles, 1971-1983).

Peters, Marion, 'From the Study of Nicolaes Witsen (1641-1717). His Life with Books and Manuscripts', Lias $21(1994 / 1)$ 1-47.

Petiver, James, Musei Petiveriani Centuria Nona \& Decima, Rariora Naturae Continens; viz. Animalia, Fossilia, Plantas, Ex variis Mundi plagis advecta, Ordine digesta, \& Nominibus propriis signata (London: S. Smith and B. Wolford, 1703).

Phillips, Andrew, and J.C. Sharman, Outsourcing Empire. How Company-States Made the Modern World (Princeton 2020).

Poelhekke, Jan, and H.C.J. Oomen, Elf brieven van Agnes Block in de universiteitsbibliotheek te Bologna (The Hague 1963).

Poullain de la Barre, François, De l'Egalité des deux sexes. Discours physique et moral, où l’on voit l'importance de se défaire des Préjugez (Paris: Antoine Dezallier 2nd ed. 1679).

Rankin, Alisha, Medicine for the Uncommon Woman. Experience, Experiment and Exchange in Early Modern Germany. PhD diss., Harvard University, 2005.

Rankin, Alisha, 'Exotic Materials and Treasured Knowledge. The Valuable Legacy of Noblewomen's Remedies in Early Modern Germany', Renaissance Studies 28 (2014/4) 533-555.

Reh, Wouter, Clemens M. Steenbergen, and Diederik Aten, Sea of Land. The Polder as an Experimental Atlas of Dutch Landscape Architecture (Wormer 2007).

Rieppel, Lukas, 'Museums and Botanical Gardens', in Bernard V. Lightman (ed.), A Companion to the History of Science (Chichester 2016) 238-251.

Rouget, François, 'Academies, Circles, "Salons," and the "Literary Public Sphere", in Bronwen Wilson and Paul Edward Yachnin (eds.) Making Publics in Early Modern Europe. People, Things, Forms of Knowledge (New York 2011) 53-67. 
Ruff, Allan R., Arcadian Visions. Pastoral Influences on Poetry, Painting and the Design of Landscape (Oxford 2015).

Schmidt, Ariadne, 'The Profits of Unpaid Work. "Assisting Labour" of Women in the Early Modern Urban Dutch Economy', History of the Family 19 (2014/3) 301-322.

Schiebinger, Londa, The Mind has No Sex? (Cambridge 1989).

Schiebinger, Londa, 'Women of Natural Knowledge', in Katherine Park and Lorraine Daston (eds.), The Cambridge History of Science. Early Modern Science (New York 2016) 192-205.

Sellers, Vanessa Bezemer, Courtly Gardens in Holland 1600-1650. The House of Orange and the Hortus Batavus (Amsterdam 2001).

Sherard, William, Schola Botanica Sive Catalogus Plantarum, quas ab aliquot annis in Horto Regio Parisiensi Studiosis indigitavit Vir Clarissimvs Joseph Pitton Tournefort, D.M.: Ut Et Pauli Hermanni P.P. Paradisi Batavi Prodromus (Amsterdam: Henricum Wetstenium, 1689).

Sprat, Thomas, History of the Royal Society of London (London 1667).

Stighelen van der, Katlijne et al., Michaelina Wautier 1604-1689. Glorifying a Forgotten Talent (Antwerp 2018).

Stighelen van der, Katlijne, and Chantal Huys, Vrouwenstreken. Vrouwelijke Schilders in de Nederlanden (1550-nu) (Amsterdam 2010).

Sutton, Elizabeth, (ed.), Women Artists and Patrons in the Netherlands, 1500-1700 (Amsterdam 2019).

Veldman, Ilja M., and Michael Hoyle, Crispjin de Passe and his Progeny (1564-1670). A Century of Print Production (Rotterdam 2001).

Vondel, Joost van, 'Mayboom voor Joan de Wolf, en Agnes Block', in J.F.M. Sterck et al. (eds.), De werken van Vondel, 10 vols. (Amsterdam 1927-1937).

Wagenberg-ter Hoeven, Anke Ariane van, Jan Weenix - the Paintings, 2 vols. (Zwolle 2018).

Whaley, Joachim, 'Public Sphere before Kant? Habermas and the Historians of Early Modern Germany', in Christian Emdem and David R. Midgley (eds.), Changing Perceptions of the Public Sphere (New York 2012).

Wilson, Bronwen, and Paul Edward Yachnin (eds.) Making Publics in Early Modern Europe. People, Things, Forms of Knowledge (New York 2011).

Zaret, David, 'Religion, Science, and Printing in the Public Spheres in Seventeenth-Century England', in Craig Calhoun (ed.), Habermas and the Public Sphere (Cambridge 1992).

Zilsel, Edgar, The Social Origins of Modern Science. Diederick Raven, Wolfgang Krohn, and Robert S. Cohen (eds.) (Dordrecht 2000).

Zwaan, M.S., 'Magdalena Poulle (1632-99). A Dutch Lady in a Circle of Botanical Collectors', Garden History 30 (2002/2) 206-220. 